\title{
PEMANFAATAN MEDIA PEMBELAJARAN IPS UNTUK MENINGKATKAN KETERAMPILAN GURU IPS TERPADU
}

\author{
UTILIZATION OF IPS LEARNING MEDIA TO IMPROVE INTEGRATED \\ TEACHERS OF IPS
${ }^{1)}$ Yulia Suriyanti, ${ }^{2)}$ Munawar Thoharudin
1,2Program Studi Pendidikan Ekonomi,
STKIP Persada Khatulistiwa Sintang \\ Jl. Pertamina Sengkuang Km.4, Kotak Pos 126, Kabupaten Sintang, Kalimantan Barat \\ email : suryantiyuli@yahoo.co.id
}

\begin{abstract}
ABSTRAK
Kegiatan ini dilaksanakan untuk guru IPS Terpadu Kabupaten Sintang. Tujuan dari kegiatan ini adalah : 1) Meningkatkan pengetahuan dan pemahaman guru tentang pentingnya penggunaan media pembelajaran dalam proses pembelajaran IPS Terpadu, 2) Meningkatkan kemampuan memilih media pembelajaran yang tepat pada setiap proses pembelajaran IPS Terpadu,3) Meningkatkan keterampilan memanfaatkan bahan-bahan sederhana serta aplikasi-aplikasi yang sudah tersedia untuk menghasilkan media pembelajaran yang tepat guna. Metode yang digunakan dalam kegiatan ini adalah: 1) Workshop tentang manfaat penggunaan media pembelajaran dalam dan cara memilih media pembelajaran yang tepat serta penggunaan berbagai media pembelajaran. 2) Pelatihan membuat media pembelajaran IPS Terpadu dengan memanfaatkan bahan sekitar yang sederhana dan aplikasi-aplikasi yang sudah tersedia. 3) pendampingan terhadap guru-guru IPS dalam menggunakan media pembelajaran yang telah di rancang pada proses pembelajaran IPS Terpadu. Hasil kegiatan berupa peningkatan kemampuan guru dalam memilih dan menentukan media pembelajaran yang tepat sesuai materi ajar, memanfaatkan sumber-sumber yang ada untuk membuat media pembelajaran dan membuat inovasi media pembelajaran IPS Terpadu.
\end{abstract}

Kata kunci : Media Pembelajaran, IPS Terpadu, Guru IPS Terpadu

\begin{abstract}
This activity was carried out for Integrated Social Studies teachers in Sintang District. The objectives of this activity are: 1) increasing teacher knowledge and understanding of the importance of using instructional media in the Integrated Social Sciences learning process, 2) Increasing the ability to choose the right learning media in each Integrated Social Sciences learning process, 3) Enhancing skills using simple materials and applications that are available to produce the right learning media. The methods used in this activity are: 1) Workshop on the benefits of using learning media and how to choose the right learning media and the use of various learning media. 2) Training to make Integrated IPS learning media by utilizing simple material around and applications that are already available. 3) assistance to social studies teachers in using learning media that have been designed in the integrated social studies learning process. The results of the activity are in the form of increasing the ability of the teacher to choose and determine the right learning media according to the teaching material, utilizing existing resources to create learning media and making integrated social media learning media innovations.
\end{abstract}

Keywords : Learning Media, Integrated Social Sciences, Integrated Social Studies Teachers 


\section{PENDAHULUAN}

IPS merupakan kajian yang terpadu dari sejumlah konsep pilihan dari cabang ilmu sosial dan ilmu lainnya melalui pendekatan pendidikan dan psikologis serta kelayakan dan kebermaknaannya bagi siswa dan kehidupannya. Menurut Nursid Mata pelajaran IPS bertujuan mengembangkan potensi peserta didik agar peka terhadap masalah sosial yang terjadi dimasyarakat, memiliki sikap mental positif terhadap perbaikan segala ketimpangan yang terjadi, dan terampil mengatasi setiap masalah yang terjadi sehari-hari baik yang menimpa dirinya sendiri maupun yang menimpa kehidupan masyarakat (Surahman \& Mukminan, 2017)

Dalam berbagai diskusi pendidikan di Indonesia, salah satu sorotan adalah mutu pendidikan yang dinyatakan rendah bila dibandingkan dengan dengan mutu pendidikan negara lain. Merujuk UndangUndang No.14 tahun 2005 tentang Guru dan Dosen disebutkan"kedudukan guru sebagai tenaga profesional berfungsi untuk meningkatkan martabat guru serta perannya sebagai agen pembelajaran untuk meningkatkan mutu pendidikan nasional". Dengan demikian secara tidak langsung hal yang harus dilakukan oleh dunia pendidikan tentunya harus mempersiapkan mutu guru yang aktif, kreatif, inovatif, dan menyenangkan.

Ironisnya metode yang digunakan oleh sebagian besar guru dalam pembelajaran saat ini adalah metode ceramah, dengan pelaksanaan pembelajaran yang berpusat pada guru, sehingga interaksi yang terlihat hanya satu arah dan guru sangat mendominasi proses pembelajaran. Hal ini ditunjang dengan tidak adanya media pembelajaran ataupun kalau ada masih bersifat konvensional yang monoton sehingga terlihat tidak menarik yang pada akhirnya peserta didik merasa bosan dan tidak tertarik. Dengan demikian siswa bersikap pasif dan tidak konsentrasi sehingga keberhasilan kegiatan belajar mengajar mungkin tidak akan tercapai sesuai harapan pendidik.

Untuk meningkatkan prestasi belajar siswa maka guru dituntut untuk membuat pembelajaran menjadi lebih inovatif yang mendorong siswa dapat belajar secara optimal baik di dalam belajar mandiri maupun didalam pembelajaran di kelas.Agar komunikasi antara guru dan siswa berlangsung baik dan informasi yang disampaikan guru dapat diterima siswa, guru perlu menggunakan media pembelajaran (Jamalludin, 2016).

Manfaat pemilihan strategi media pembelajaran adalah siswa mendapat layanan yang baik dalam pemahaman materi pelajaran karena meteri dapat diterima dengan cepat melalui bantuan media pembejaran; meningkatkan prestasi belajar siswa karena materi secara maksimal dapat diserap oleh siswa dengan menggunakan media pembelajaran yang tepat (Prastya, 2016).

Untuk itu sangat penting kiranya pemilihan media pembelajaran yang tepat sehingga memberikan banyak manfaat. Dengan menggunakan media pendidikan secara tepat dan bervariasi dapat di atasi sikap pasif peserta didik. Dalam hal ini media pembelajaran berguna untuk: Menimbulkan kegairahan belajar; Memungkinkan interaksi yang lebih langsung antara anak didik dengan lingkungan kenyataan; Memungkinkan peserta didik belajar sendiri-sendiri menurut kemampuan dan minatnya (Ramli, 2015).

Secara umum dapat dinyatakan bahwa media pembelajaran adalah segala sesuatu yang dapat dipergunakan untuk merangsang pikiran, perasaan, perhatian dan kemampuan atau ketrampilan pebelajar sehingga dapat mendorong terjadinya proses belajar. Menurut Setyawan (2016:2) media adalah "segala 
sesuatu yang dapat digunakan untuk menyampaikan pesan dari guru kepada siswa sehingga dapat merangsang pikiran, perasaan, perhatian dan minat siswa yang menjurus memproses pesan-pesan dalam materi pelajaran yang disampaikan". Oleh karena proses pembelajaran merupakan proses komunikasi antara guru dengan siswa, maka media pembelajaran menempati posisi yang cukup penting sebagai salah satu komponen sistem pembelajaran. Media pembelajaran adalah komponen integral dari sistem pembelajaran. Tanpa media, komunikasi akan kurang efektif dan proses pembelajaran sebagai proses komunikasi juga tidak akan bisa berlangsung secara optimal.

Pengabdian ini dimaksudkan untuk membekali guru IPS SMP yang tergabung dalam MGMP IPS Kabupaten Sintang mengenai pentingnya penggunaan media dalam proses pembelajaran. Dipilihnya guru IPS SMP yang tergabung dalam MGMP karena potensial untuk dikembangkan. Melalui kegiatan ini guru diharapkan dapat berinovasi dalam penggunaan pembelajaran sehingga dapat meningkatkan mutu dirinya sesuai dengan tuntutan guru yang profesional, sebagaimana tuntutan UU Guru dan Dosen.

Berdasarkan hasil penelitian Rahmawati \& Baharuddin (2016) disimpulkan bahwa media pembelajaran animasi lebih baik diterapkan pada siswa yang memiliki gaya belajar visual sedangkan media pembelajaran gambar diam akan lebih baik diterapkan pada siswa yang memiliki gaya belajar auditori serta terdapat interaksi antara media pembelajaran dan gaya belajar dalam mempengaruhi hasil belajar siswa. Sedangkan hasil penelitian Rahmattullah, (2011) menyimpulkan, ada perbedaan hasil belajar siswa di kelas yang menggunakan media pembelajaran film animasi sebelum dan sesudah perlakuan. Setyawan (2016) mengatakan media power point dengan segala kelebihannya membuat siswa lebih tertarik, lebih fokus, lebih konsentrasi, sehingga peserta didik lebih aktif dalam belajar dan termotivasi untuk mencari dan menemukan sesuatu yang baru".

Tujuan dari kegiatan ini adalah: 1) Meningkatkan pengetahuan dan pemahaman guru terhadap pentingnya penggunaan media pembelajaran dalam proses pembelajaran IPS Terpadu, 2) Meningkatkan kemampuan memilih media pembelajaran yang tepat pada setiap proses pembelajaran IPS Terpadu, 3) Meningkatkan keterampilan memanfaatkan bahan-bahan sederhana serta aplikasi-aplikasi yang sudah tersedia untuk menghasilkan media pembelajaran yang tepat guna.

\section{METODE}

Kegiatan yang dilakukan adalah workshop dengan metode Ceramah bervariasi. Metode ini dipilih dengan pertimbangan bahwa metode ceramah yang dikombinasikan dengan gambar-gambar, animasi dan display dapat memberikan materi yang relatif banyak secara padat, cepat dan mudah.

Kegiatan selanjutnya adalah pelatihan dengan metode demonstrasi dan simulasi serta praktek pembuatan media IPS Terpadu. Demonstrasi yang ditampilkan yaitu media pembelajaran berbahan dasar barang-barang bekas, styrofoam dan kertas origami, media pembelajaran kartu, media pembelajaran video edukasi, dan media pembelajaran berbasis Powerpoint, android, adobe flash dan media pembelajaran berbasis youtube. Setelah demonstrasi oleh pemateri, selanjutnya peserta dipersilahkan untuk membuat media pembelajaran sebagaimana yang telah dicontohkan oleh pemateri 
Kegiatan selanjutnya adalah pendampingan penggunaan media dalam Pembelajaran IPS Terpadu. Pendampingan dilaksanakan saat guru-guru IPS Terpadu melaksanakan pembelajaran secara langsung. Pada pendampingan ini, tim PKM memantau penggunaan media oleh guru dan memberikan masukan terkait kendala yang dialami oleh guru dalam menggunakan media tersebut. Selain itu, tim PKM juga guru yang bersangkutan menuliskan beberapa temuan terkait masalah yang dihadapi saat penggunaan media tersebut. Akhir kegiatan guru dan tim PKM melaksanakan diskusi dan refleksi terkait upaya perbaikan media pembelajaran yang telah digunakan. Selanjutnya tim PkM meminta masukan dari guru-guru MGMP IPS Terpadu tentang kegiatan yang telah dilaksanakan melalui angket yang disebarkan kepada seluruh peserta. Proses evaluasi dilaksanakan untuk mengetahui kekurangan dan kendala dalam pelaksanaan kegiatan.

\section{HASIL DAN PEMBAHASAN}

Hasil kegiatan ditunjukan dengan ketercapaian guru-guru dalam membuat media pembelajaran adalah $87,5 \%$. Beberapa kendala yang dihadapi saat membuat media pembelajaran adalah dikarenakan guru-guru kurang menguasai penggunaan android, laptop dan internet. Berikut salah satu contoh media pembelajaran IPS Terpadu yang dibuat oleh guru-guru IPS Terpadu Kabupaten Sintang.

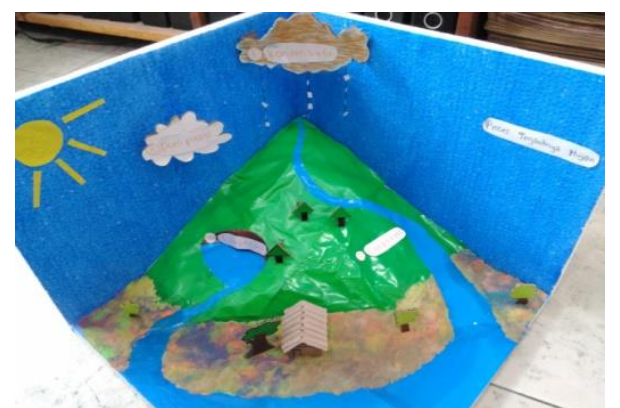

Gambar 1. Media pembelajaran IPS Terpadu "proses terjadinya hujan".

Evaluasi saat pendampingan penggunaan media oleh guru-guru IPS Terpadu menunjukkan ketercapaian mencapai $78,1 \%$. Catatan oleh tim PKM dan guru dikarenakan guru mengalami kebingungan dalam menggunakan media yang telah dirancang. Selain itu, beberapa guru mengalami masalah interaksi dengan siswa saat menggunakan media. Akan tetapi, secara keseluruhan kegiatan ini berjalan dengan lancar dan berhasil dilaksanakan.

Melalui kegiatan ini pengetahuan guru MGMP IPS Kabupaten Sintang tentang media pembelajaran menjadi meningkat. Melalui angket yang diberikan pada akhir kegiatan, peserta mengungkapkan bahwa dengan adanya penggunaan media dalam pembelajaran mampu meningkatkan minat serta antusiasme siswa terhadap pembelajaran IPS Terpadu. Hal ini sejalan dengan hasil penelitian oleh Magdalena dan Astikawati (2017) yang menyatakan bahwa penggunaan media audio visual dalam pelajaran ekonomi mampu menarik perhatian siswa dalam belajar dan dapat memberikan motivasi belajar dan kemudahan kepada siswa untuk memahami materi yang disampaikan guru, dengan cara guru menampilkan materi yang dibahas melalui Microsoft powerpoint. Selain itu, beberapa media pembelajaran yang dihasilkan oleh guru dengan memanfaatkan bahan-bahan sederhana yang ada disekitar dapat meningkatkan kreatifitas guru dalam 
menciptakan media pembelajaran. Adapun beberapa bahan sederhana yang digunakan adalah kertas koran bekas, papan triplek bekas serta tumbuh-tumbuhan sekitar yang telah tidak dapat berfungsi dengan baik seperti daun pisang yang sudah layu.

\section{SIMPULAN}

Berdasarkan kegiatan yang telah dilaksanakan dapat simpulkan hasil yang dicapai melalui kegiatan tersebut yaitu: 1) Adanya peningkatan pengetahuan para guru tentang media pembelajaran yang sesuai dengan mata pelajaran IPS Terpadu; 2) Guru mampu memilih media pembelajaran dalam pembelajaran IPS terpadu; 3) Guru dapat mengembangkan dan menciptakan media pembelajaran IPS terpadu; 4) Guru dapat membuat media pembelajaran yang tepat sesuai pembelajaran IPS terpadu, 5) Guru dapat mengembangkan media pembelajaran berbasis IT (Pembelajaran Interaktif).

\section{DAFTAR PUSTAKA}

Jamaludin., (2016). Manfaat Media Komunikasi Dalam Pendidikan Dan Pembelajaran. At-Tabligh, 1(1).

Prastya, A., (2016). Strategi Pemilihan Media Pembelajaran Bagi Seorang Guru. Prosiding, Temu Ilmiah Nasional Guru (TING) VIII, (26 November 2016), 632-641.

Rahmattullah, M., (2011). Pengaruh Pemanfaatan Media Pembelajaran Film Animasi Terhadap Hasil Belajar. Jurnal Penelitian Pendidikan, 1(1), 178-186.

Rahmawati, S., \& Baharuddin. (2016). Pengaruh Media Pembelajaran Dan Gaya Belajar Terhadap Hasil Belajar Ips Terpadu Siswa Kelas Viii Smp Negeri 1 Badar dan SMP Negeri 5 Badar Kab. Aceh Tenggara. Jurnal Teknologi Informasi \& Komunikasi
Dalam Pendidikan, 3(1).

Ramli, M. (2015). Media Pembelajaran Dalam Perspektif Al-Qur'an Dan AlHadits. Ittihad Jurnal, 13(23), 130154.

Surahman, E., \& Mukminan. (2017). Peran Guru IPS Sebagai Pendidik Dan Pengajar Dalam Meningkatkan Sikap Sosial Dan Tanggung Jawab Sosial Siswa SMP. Harmoni Sosial: Jurnal Pendidikan IPS, 4(1), 1-13. 